\title{
Optimization of preparation conditions for rice husk based activated carbons for the removal of methylene blue dye
}

\author{
Murat $\mathrm{MN}^{1}$, Mohd Azmier Ahmad ${ }^{1,3 *}$ and Mohd Nazri Idris ${ }^{2}$ \\ ${ }^{1}$ School of Chemical Engineering, Engineering Campus, Universiti Sains Malaysia, 14300 Nibong Tebal, Penang, Malaysia \\ ${ }^{2}$ Solid Waste Management Cluster, Science \& Engineering Research Centre, Engineering Campus, Universiti Sains Malaysia, Nibong \\ Tebal, Penang, Malaysia \\ ${ }^{3}$ School of Materials and Mineral Resources Engineering, Engineering Campus, Universiti Sains Malaysia, 14300 Nibong Tebal, Penang, \\ Malaysia
}

\section{Article Info}

*Corresponding author:

Mohd Azmier Ahmad

School of Chemical Engineering

Engineering Campus, Universiti Sains Malaysia

14300 Nibong Tebal

Penang, Malaysia

Tel: +604 5996459

Fax: +6045996908

E-mail: chazmier@usm.my

Received: July 25, 2018

Accepted: August 25, 2018

Published: August 31, 2018

Citation: Murat MN, Ahmad MA, Idris MN. Optimization of preparation conditions for rice husk based activatedcarbons for the removal of methylene blue dye. Int $J$ Petrochem Res. 2018; 2(2): 186-188.

doi: 10.18689/ijpr-1000133

Copyright: (c) 2018 The Author(s). This work is licensed under a Creative Commons Attribution 4.0 International License, which permits unrestricted use, distribution, and reproduction in any medium, provided the original work is properly cited.

Published by Madridge Publishers

\begin{abstract}
This study investigates the optimal conditions for preparation of rice husk based activated carbon (RHAC) using carbon dioxide gasification of rice husk char undermicrowave irradiation.The central composite design (CCD) was used todetermine the effects of the two preparation variables; microwave power and activation time on MB removal and RHAC yield. Basedon the $C C D$, a quadratic model and linear modelswere developed for $M B$ removal and RHAC yield, respectively. The significant factors on each experimental design responsewere identified from the analysis of variance (ANOVA). The optimum conditions for RHAC preparation were obtained by using activation time of $4.28 \mathrm{~min}$ and microwave power of $440 \mathrm{~W}$, which resulted MB removal of $83.05 \%$ and RHAC yield of $31.98 \%$.
\end{abstract}

Keywords: Activated carbon, Adsorption, Methylene blue, Microwave heating,Optimization, Rice husk

\section{Introduction}

The textile industry uses dyes to color their product consume large quantities of water [1]. More than 100,000 commercially available dyes with over $7 \times 10^{5}$ tonnes of dyestuff produced every year have been estimated [2]. At the same time, massive amount of textile wastewater is produced during dyeing and finishing processes. One of the serious issues associated with textile wastewater is colored effluent as they produce an obvious color to water even at low concentration [3]. Therefore, the appearance of dyes onto streams and rivers are categorized as threatening pollutant that should not be neglected. Indeed, removal of dyes from the effluent before its disposal in water bodies is very important [4]. In the last few years, great attention has been placedon utilizing waste as precursor for producing lowcost activated carbon. In this study an attempt was made to find the optimum preparation condition of producing activated carbon from rice husk waste.

\section{Methodology}

The rice husk was placed in a Pyrex glass reactor in the chamber of the microwave oven. The microwave irradiation was carried at targeted radiation time and radiation power under carbon dioxide flow of $150 \mathrm{ml} / \mathrm{min}$ as suggested by the Design Expert software. The response surface methodology (RSM) design known as central composite design (CCD) was used in this study. The variables involved were microwave power $\left(x_{1}\right)$ and activation time $\left(\mathrm{x}_{2}\right)$ with MB removal $\left(\mathrm{y}_{1}\right)$ and RHAC yield $\left(\mathrm{y}_{2}\right)$ as responses. The code levels for CCD are shown in Table 1. 
Table 1. Independent variables and their coded levels for the CCD

\begin{tabular}{|c|c|c|c|c|c|}
\hline \multirow{2}{*}{ Variables (factors) } & \multicolumn{5}{|c|}{ Coded variables level } \\
\cline { 2 - 6 } & $-\alpha$ & -1 & 0 & +1 & $+\alpha$ \\
\hline Microwave power (W) & 191 & 264 & 440 & 616 & 689 \\
Activation time (min) & 3.17 & 4.00 & 6.00 & 8.00 & 8.83 \\
\hline
\end{tabular}

\section{Results and discussion}

The response values that obtained from the experimental works using the design of expert software are shown in Table 2. The polynomial regression equation was developed using CCD. As suggested by the software, the quadratic and linear models were selected for $\mathrm{MB}$ removal $\left(\mathrm{Y}_{1}\right)$ and $\mathrm{RHAC}$ yield $\left(\mathrm{Y}_{2}\right)$, respectively as the best model to correlate the data to the response.

Table 2. Response values of the experimental works

\begin{tabular}{|c|c|c|c|}
\hline \multicolumn{2}{|c|}{ RHAC preparation variable } & \multirow{2}{*}{$\begin{array}{c}\text { MB removal, } \\
Y_{1}(\%)\end{array}$} & \multirow{2}{*}{$\begin{array}{c}\text { RHAC yield, } \\
Y_{2}(\%)\end{array}$} \\
\hline $\begin{array}{c}\text { Microwave power, } \\
x_{1}(\mathrm{~W})\end{array}$ & $\begin{array}{c}\text { Activation time, } \\
x_{2}(\min )\end{array}$ & & \\
\hline 440 & 6.00 & 89.95 & 27.00 \\
\hline 616 & 8.00 & 91.61 & 26.67 \\
\hline 264 & 8.00 & 79.42 & 34.00 \\
\hline 440 & 8.83 & 90.18 & 25.67 \\
\hline 440 & 6.00 & 89.11 & 27.67 \\
\hline 440 & 6.00 & 90.46 & 28.00 \\
\hline 616 & 4.00 & 90.59 & 27.00 \\
\hline 440 & 3.17 & 73.67 & 31.33 \\
\hline 440 & 6.00 & 90.54 & 29.00 \\
\hline 689 & 6.00 & 94.12 & 19.00 \\
\hline 191 & 6.00 & 70.96 & 44.33 \\
\hline 264 & 4.00 & 72.79 & 36.60 \\
\hline 440 & 6.00 & 89.90 & 28.00 \\
\hline
\end{tabular}

The final empirical models for MB removal and RHAC in term of coded factors are shown in Equation Equations 1 and 2 respectively,

The correlation coefficient, $R^{2}$ value were used to evaluate the suitability of model equation. The model developed is the best at low standard deviation and high $\mathrm{R}^{2}$ statistic which is closer to the unity. The $R^{2}$ values for Equations 1 and 2 were 0.9546 and 0.9052 , respectively. The higher $R^{2}$ values indicate that the predicted values for MB removal and RHAC were closer to its actual value [5].

Analysis of variance (ANOVA) was carried out to justify the adequacy of the models. The ANOVA for the quadratic model of MB removal is shown in Table 3, where the F-value of 29.45 and Prob>F is 0.0001 prove that the model is significant. The microwave power $\left(\mathrm{x}_{1}\right)$, activation time $\left(\mathrm{x}_{2}\right)$, quadratic term of microwave power $\left(x_{1}^{2}\right)$ and the quadratic terms of activation time $\left(\mathrm{x}_{2}^{2}\right)$ were significant model terms whereas the interaction terms $\left(x_{1} x_{2}\right)$ were insignificant to the response.

Table 3. ANOVA for MB removal by RHAC

\begin{tabular}{|c|c|c|c|c|c|}
\hline Source & $\begin{array}{c}\text { Sum of } \\
\text { squares }\end{array}$ & $\begin{array}{c}\text { Degree of } \\
\text { freedom (DF) }\end{array}$ & $\begin{array}{c}\text { Mean } \\
\text { square }\end{array}$ & F-Value & Prob.>F \\
\hline Model & 774.44 & 5 & 154.89 & 29.45 & 0.0001 \\
$x_{1}$ & 492.09 & 1 & 492.09 & 93.55 & $<0.0001$ \\
$x_{2}$ & 120.11 & 1 & 120.11 & 22.83 & 0.0020 \\
$x_{1} X_{2}$ & 7.87 & 1 & 7.87 & 1.50 & 0.2609 \\
$x_{1}^{2}$ & 79.64 & 1 & 79.64 & 15.14 & 0.0060 \\
$x_{2}^{2}$ & 94.77 & 1 & 94.77 & 18.02 & 0.0038 \\
\hline
\end{tabular}

Table 4 shows the ANOVA for quadratic model for RHAC yield. The model F-value of 17.65 and Prob>F of 0.0005 indicates the model is significant. Based on the result obtained, microwave power $\left(x_{1}\right)$ and the activation time $\left(x_{2}\right)$ were significant model terms.
Table 4. ANOVA for RHAC yield

\begin{tabular}{|c|c|c|c|c|c|}
\hline Source & $\begin{array}{c}\text { Sum of } \\
\text { squares }\end{array}$ & $\begin{array}{c}\text { Degree of } \\
\text { freedom }\end{array}$ & $\begin{array}{c}\text { Mean } \\
\text { square }\end{array}$ & F-Value & Prob. $>\mathrm{F}$ \\
\hline Model & 339.18 & 2 & 169.59 & 17.65 & 0.0005 \\
$x_{1}$ & 287.32 & 1 & 287.32 & 29.90 & 0.0003 \\
$x_{2}$ & 51.09 & 1 & 51.85 & 5.40 & 0.0426 \\
\hline
\end{tabular}

Three-dimensional surface response and contour plots were constructed to assess the interactive relationships between independent variables and responses of certain models. Figure 1 shows three-dimensional surface responses for two factors microwave power and activation time on MB removal.

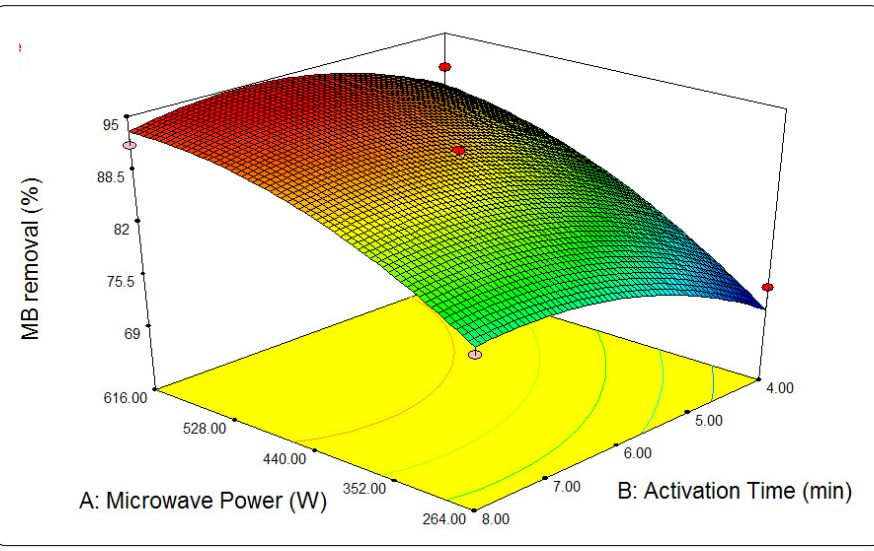

Figure 1. Three-dimensional response surface plot of MB removal by RHAC

High microwave powerpromotes the development of pores on the sample, thus resulted high response value. Figure 2 shows the three-dimensional response surface of the combined effect of microwave power and activation time on the RHAC yield. All variable were significant on the response with microwave power imposing greater effect than activation time. Increase the microwave power, significantly more pores and active site were developed on the RHAC surface. Therefore the yield decreases with increasing activation time due to more release of volatile matter.

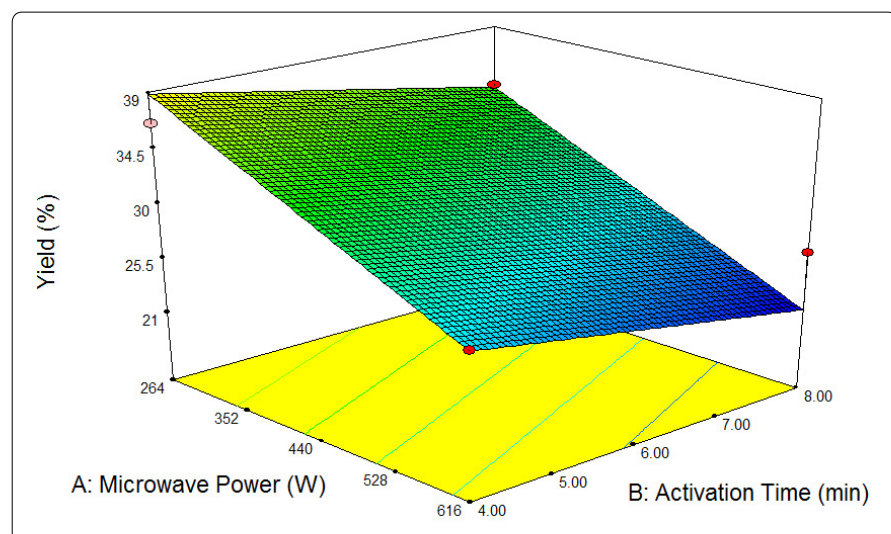

Figure 2. Three-dimensional response surface plot of RHAC yield

The aim of this study is to obtain the optimum parameters of RHAC produced with highest RHAC yield and MB removal. Design Expert software was used to compromise between yield and MB removal while optimizing both of these values by selecting the highest responses from the experimental result. The optimum operating conditions is depending on achieving high MB removal. The experimental conditions with the highest desirability are shown in the Table 5. 
Table 5. Model validation for MB removal and RHAC yield

\begin{tabular}{|c|c|c|c|c|c|c|c|}
\hline \multirow{2}{*}{ 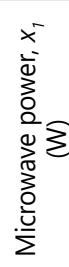 } & \multirow{2}{*}{ 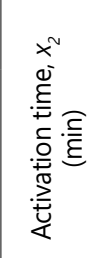 } & \multicolumn{3}{|c|}{$\begin{array}{c}\text { MB removal } \\
(\%)\end{array}$} & \multicolumn{3}{|c|}{ RHAC yield (\%) } \\
\hline & & 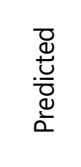 & 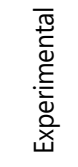 & 帝 & 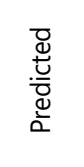 & 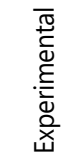 & 旁 $\widehat{\varrho}$ \\
\hline 440 & 4.28 & 83.93 & 83.05 & 1.05 & 32.55 & 31.98 & 1.75 \\
\hline
\end{tabular}

The optimum preparation conditions were obtain at activation time of $4.28 \mathrm{~min}$ and microwave power of $440 \mathrm{~W}$, which resulted MB removal of $83.05 \%$ and $\mathrm{RHAC}$ yield of $31.98 \%$. The error for the MB removal and RHAC yield between the experimental and predicted value are $1.05 \%$ and $1.75 \%$, respectively, which indicates sufficient accuracy of the process optimization.

\section{Conclusion}

Response surface methodology was successfully used to investigatethe effects of microwave power and activation time on the MB removal and RHAC yield. The optimum RHAC preparationconditions were obtained using activation time of $4.28 \mathrm{~min}$ and microwave power of $440 \mathrm{~W}$, which resulted MB removal of $83.05 \%$ and RHAC yield of $31.98 \%$. Through analysis of the response surface,microwave power and activation time were found to have significant effectson $M B$ removal and RHAC yield.

\section{Acknowledgements}

The authors are grateful for the funding from Solid Waste Management Cluster (RU 1001/CKT/870023) and Bridging Grant of UniversitiSains Malaysia.

\section{References}

1. Bello OS, Siang TT, Ahmad MA. Adsorption of Remazol Brilliant Violet-5R reactive dye from aqueous solution by cocoa pod husk-based activated carbon: Kinetic, equilibrium and thermodynamic studies. Asia-Pacific Journal of Chemical Engineering. 2012; 7: 378-388. doi: 10.1002/apj.557

2. Ahmad MA, Rahman NK. Equilibrium, kinetics and thermodynamic of Remazol Brilliant Orange 3R dye adsorption on coffee husk-based activated carbon. Chemical Engineering Journal. 2011; 170(1: 154-161. doi: 10.1016/j.cej.2011.03.045

3. Yener J, Kopac T, Dogu G, Dogu T. Dynamic analysis of sorption of Methylene Blue dye on granular and powdered activated carbon. Chemical Engineering Journal. 2008; 144: 400-406. doi: 10.1016/j. cej.2008.02.009

4. Govindwar SP, Kurade MB, Tamboli DP, Kabra AN, Kim PJ, Waghmode TR. Decolorization and degradation of xenobiotic azo dye Reactive Yellow84A and textile effluent by Galactomycesgeotrichum. Chemosphere. 2014; 109: 234-38. doi: 10.1016/j.chemosphere.2014.02.009

5. Sahu JN, Acharya J, Meikap BC. Optimization of production conditions for activated carbons from Tamarind wood by zinc chloride using response surface methodology. Bioresource Technology. 2010; 101(6): 1974-1982. doi: 10.1016/j.biortech.2009.10.031 